\title{
Ceramic Wastes Usage as Alternative Aggregate in Mortar and Concrete
}

\author{
Gulden Cagın Ulubeyli', Turhan Bilir ${ }^{1}$, Recep Artir ${ }^{2}$ \\ ${ }^{1}$ Department of Civil Engineering, Bulent Ecevit University \\ ${ }^{2}$ Department of Metallurgical and Materials Engineering, Marmara University
}

\begin{tabular}{l} 
Article Info \\
\hline Article history: \\
Received May $29^{\text {th }}, 2017$ \\
Revised June $15^{\text {th }}, 2017$ \\
Accepted June $17^{\text {th }}, 2017$ \\
\hline
\end{tabular}

Keyword:

Aggregate

Ceramic Waste

Concrete

Durability Properties

Mechanical Properties

\begin{abstract}
In the ceramic industry, huge amounts of wastes are generated during manufacturing and transportation processes. In order to decrease the need for landfill areas and increase environmentally harmful effects of such wastes, this industry is under pressure to finding effective ways for recycling its wastes and by-products. In addition, the construction industry requires new sources of aggregates due to running out of conventional virgin aggregates, saving energy, and protecting the environment. Therefore, recently, ceramic wastes are often used as coarse and/or fine aggregate both in mortar and concrete. In the present study, effects of using ceramic wastes as coarse and/or fine aggregate on the engineering properties of mortar and concrete are evaluated. These engineering properties are listed and compared according to their mechanical and durability properties. Reviewing of previous studies related with this subject in literature and discussion all results of the studies are conducted as the methodology of this study. Consequently, it was found out that the use of waste ceramic in the conventional concrete or mortar mix as fine/coarse aggregate is suitable as it can improve mechanical and durability properties of the concrete/mortar.
\end{abstract}

\section{Corresponding Author:}

Gulden Cagin Ulubeyli, Department of Civil Engineering, Bulent Ecevit University, Farabi Campus, İncivez 67100, Zonguldak, Turkey. Email: caginulubeyli@ beun.edu.tr

\section{Introduction}

Recycling and reutilization of industrial waste and byproducts is a subject of great importance today in cement and concrete technology [1]. Especially ceramic wastes, which are durable, hard and highly resistant to biological, chemical and physical degradation forces, cannot be recycled by any existing process. The use of inorganic industrial residual products in the production of concrete will lead to sustainable ceramic industry ranges from 3\% to $7 \%$ of daily production [2]. Therefore, construction industry can be the end user of all ceramic wastes and in this way can contribute to solve this environmental problem. The nature of construction industry, especially the concrete industry, is such that ceramic wastes can be used safely with no need for dramatic change in production and application process. On the other hand, the cost of deposition of ceramic waste in landfill will be saved and, on the other, raw materials and natural resources will be replaced, thus saving energy and protecting the environment [3].

In the present study, the effects of ceramic wastes used as fine/coarse aggregates on the properties of concrete were investigated by an in-depth literature review. Thus, the effect of these ceramic wastes on the durability and mechanical properties of concrete and mortar were presented in a detailed manner. Consequently, the use 
of ceramic wastes and their effects as fine/coarse aggregates in a sustainable concrete and mortar were examined.

\section{Methodology}

In this study, considering the previous studies, mechanical and durability properties of concrete produced by waste ceramic addition into mortar and concrete investigated in detailed manner. Throughout the literature review, it was observed that ceramic waste was used as fine/coarse aggregate in sand/gravel in producing mortar/concrete mix. In these studies, effects of waste ceramic on the some mechanical and durability properties of concrete were investigated. In this study, mechanical properties grouped into compressive, flexural and tensile strength, elastic modulus and finally shrinkage of concrete. In addition to, durability properties grouped into water absorbtion, ultrasonic pulse velocity, chloride penetration, abrasion resistance and finally freeze-thaw resistance. Consequently, effects of waste ceramic on these properties of concrete were evaluated in a detailed manner and reasons of results were established.

\section{Results and Discussion}

\subsection{Mechanical Properties}

Mechanical properties of results were summarized in Table 1. Considering the results, waste ceramic was used as fine or/and coarse aggregate in concrete/mortar mixing. When ceramic waste was used as fine or/and coarse aggregate in concrete or mortar mixing, strength properties of concrete were increased compared with control concrete/mortar in generally. This improved incorporation of waste ceramic aggregate in the paste can be due to the more irregular shape it presents, resulting in a superior specific surface area than natural aggregate (gravel), which is rounded and thus lacks edges. Moreover, this irregular shape provides the higher bond between recycled ceramic aggregate and the paste. Furthermore, the ceramic aggregate could presented little puzzolanic activity in the surface part due to its chemical composition and grain size, this was nevertheless sufficient to react with the porltandite present in the periphery of the aggregate, giving rise to hydrated products such as calcium silicate hydrates $(\mathrm{CSH})$ and calcium aluminate hydrates which present a less porous, more compact structure, forming a more stable aggregate/paste transition zone [4]. In contrast to all these studies, a few studies consisted of low strength properties compared to conventional concrete/mortar detected [5]-[6]. In these studies, the reason of strength loss was explained as ceramic aggregate having lower density and strength compared to conventional aggregate [6].

\subsection{Durability Properties}

Durability properties of results were summarized in Table 2. According to results of studies, chloride penetration, capillarity water absorbtion, abrasion resistance, freeze-thaw resistance, high temperature resistance, gas permeability and finally, ultrasonic pulse velocity properties were investigated in previous studies. Especially, capillary water absorbtion, oxygen and gas permeability of concrete produced waste ceramic as fine/coarse aggregate were improved or similar compared to conventional concrete. But, these properties were determined as worse compared to control specimen [7]-[8]. This decrease can be due to both the higher water absorption coefficient in waste ceramic aggregate and the effect of this waste ceramic aggregate on the pore system [9]. In generally, freeze-thaw durability and high temperature resistance, chloride penetration and abrasion resistance performance of concrete produced by waste ceramic were better than conventional concrete due to the high mechanical and the puzolonic properties of the ceramic aggregate [4]. 
Table 1. Comparison of some results for mechanical properties.

\begin{tabular}{|c|c|c|c|c|c|c|c|c|}
\hline \multirow[b]{2}{*}{$\begin{array}{l}\text { Type of } \\
\text { Product }\end{array}$} & \multirow[b]{2}{*}{$\begin{array}{l}\text { Using of Waste } \\
\text { Ceramic In The } \\
\text { Concrete }\end{array}$} & \multicolumn{2}{|c|}{ Mixing Ratio of Concrete } & \multirow[b]{2}{*}{$\begin{array}{c}\text { Comparison } \\
\text { Criteria }\end{array}$} & \multirow[b]{2}{*}{ Experiments } & \multirow[b]{2}{*}{ Curing Day } & \multirow[b]{2}{*}{ Mechanical Property Findings } & \multirow[b]{2}{*}{ Ref. } \\
\hline & & $\begin{array}{c}\text { Waste Ceramic } \\
\text { Type }\end{array}$ & \begin{tabular}{|c} 
Waste Ceramic \\
Ratio
\end{tabular} & & & & & \\
\hline $\begin{array}{c}\text { Normal } \\
\text { MortarMixing }\end{array}$ & $\begin{array}{c}\text { As Fine Aggregate } \\
\text { in Sand }\end{array}$ & $\begin{array}{l}\text { Earthenware } \\
\text { ceramic waste } \\
\text { (CWA) }\end{array}$ & $\begin{array}{c}(10-20-30-40-50- \\
100) \%\end{array}$ & $\begin{array}{l}\text { Mortar mix produced } \\
\text { by } \% 100 \text { natural sand }\end{array}$ & -Compressive Strength & 7,14 and 28 & $\begin{array}{l}\text { All mortar mixes containing CWA gave higher compres sive } \\
\text { strength than that of the control mortar ( } 42.2 \mathrm{MPa} \text { at } 28 \text { days), } \\
\text { and that the compres sive strength increased with increasing use } \\
\text { of CWA up to } 50 \% \text { by weight ( } 50.2 \mathrm{MPa} \text { at } 28 \text { days). }\end{array}$ & [10] \\
\hline $\begin{array}{c}\text { Normal } \\
\text { MortarMixing }\end{array}$ & $\begin{array}{l}\text { As Fine Aggregate } \\
\text { in Sand }\end{array}$ & $\begin{array}{l}\text { Porcelain } \\
\text { insulator waste } \\
\text { (CWA) }\end{array}$ & $100 \%$ & $\begin{array}{l}\text { Mortar mix produced } \\
\text { by } \% 100 \text { typical river } \\
\text { sand (RS) }\end{array}$ & -Compressive Strength & $7,28,91$ & $\begin{array}{l}\text { The compressive strength of the CWA mortars in which the } \\
\text { CWA was used as received from the recycle plant was } \\
\text { relatively similar to that of the corresponding RS mortars. }\end{array}$ & [11] \\
\hline $\begin{array}{c}\text { Conventional } \\
\text { Concrete }\end{array}$ & $\begin{array}{c}\text { As Fine Aggregate } \\
\text { in Sand }\end{array}$ & $\begin{array}{l}\text { Earthenware } \\
\text { ceramic waste } \\
\text { (CWA) }\end{array}$ & $(50-100) \%$ & $\begin{array}{l}\text { Concrete mix produced } \\
\text { by } \% 100 \text { natural sand }\end{array}$ & -Compressive Strength & 7 and 28 & $\begin{array}{l}\text { The compressive strength at } 28 \text { days of (CWA) concrete } \\
\text { increased with the use of CWA at } 50 \% \text { by weight, where it } \\
\text { reached optimum strength ( } 40 \mathrm{MPa}) \text {. This was an increase of } \\
7.5 \% \text { compared to the control concete. Thereafter a decline in } \\
\text { compressive strength was observed, with a slightlylowervalue } \\
(38.5 \mathrm{MPa}) \text { at } 100 \% \mathrm{CWA} \text {. }\end{array}$ & [10] \\
\hline $\begin{array}{c}\text { Conventional } \\
\text { Concrete }\end{array}$ & $\begin{array}{l}\text { As Fine Aggregate } \\
\text { in Sand }\end{array}$ & $\begin{array}{l}\text { White ceramic } \\
\text { powder }\end{array}$ & $\begin{array}{c}(10-20-30-40- \\
50) \%\end{array}$ & $\begin{array}{l}\text { Concrete mix produced } \\
\text { by } \% 100 \text { natural sand }\end{array}$ & \begin{tabular}{|l|}
-Compressive Strength \\
-Tensile (Brazilian) Test \\
-Flexi-traction Test
\end{tabular} & $7,14,28$ & $\begin{array}{l}\text { The use of white ceramic powder to substitute part of the sand } \\
\text { does not reduce compressive strength but rather gives an } \\
\text { appreciable increase in strength. Regarding traction resistance, } \\
\text { the introduction of white ceramic powder does not give any } \\
\text { appreciable difference compared with the control concrete. }\end{array}$ & [12] \\
\hline $\begin{array}{c}\text { Conventional } \\
\text { Concrete }\end{array}$ & $\begin{array}{c}\text { As Fine Aggregate } \\
\text { in Sand }\end{array}$ & $\begin{array}{c}\text { Crushed ceramic } \\
\text { waste (CC) }\end{array}$ & $(40-50-60) \%$ & $\begin{array}{l}\text { Concrete mix produced } \\
\text { by } \% 100 \text { conventional } \\
\text { crushed fine aggregates }\end{array}$ & -Compressive Strength & $7,28,90,365$ & $\begin{array}{l}\text { It can be seen that the compressive strength of CC concrete } \\
\text { mixes with } 40 \%, 50 \% \text { and } 60 \% \text { fine aggregate replacement } \\
\text { with CC were higher than the control specimen at all ages } \\
\text {.However, the rate of increase of strength decreases with the } \\
\text { increase in CC content. }\end{array}$ & [13] \\
\hline $\begin{array}{c}\text { Conventional } \\
\text { Concrete }\end{array}$ & $\begin{array}{l}\text { As Fine Aggregate } \\
\text { in CEN Reference } \\
\text { Sand }\end{array}$ & $\begin{array}{c}\text { Sanitary ceramic } \\
\text { waste }\end{array}$ & $(10,15$ and 20$) \%$ & $\begin{array}{l}\text { Concrete mix produced } \\
\text { by } \% 100 \text { natural sand }\end{array}$ & $\begin{array}{l}\text {-Compressive Strength } \\
\text {-Flexural Strength }\end{array}$ & $\begin{array}{c}2,7,14,28 \\
56\end{array}$ & $\begin{array}{l}\text { Incorporation of ceramic waste aggregates led to a systematic } \\
\text { improvement of the mechanical properties, the benefits } \\
\text { increasing with the addition rate. }\end{array}$ & [14] \\
\hline $\begin{array}{c}\text { Conventional } \\
\text { Concrete }\end{array}$ & $\begin{array}{l}\text { As Fine and coarse } \\
\text { aggregate in sand } \\
\text { and gravel }\end{array}$ & $\begin{array}{l}\text { Brick, blocks and } \\
\text { roof tiles - wall, } \\
\text { floor tiles and } \\
\text { sanitary ware }\end{array}$ & $\begin{array}{r}100 \% \text { (for both } \\
\text { fine and coarse) }\end{array}$ & $\begin{array}{l}\text { Concrete mix produced } \\
\text { by } \% 100 \text { natural fine } \\
\text { and coarse aggregate }\end{array}$ & -Compressive Strength & $\begin{array}{l}7,14,28,56 \\
\text { and } 90\end{array}$ & $\begin{array}{l}\text { The results obtained indicate that the strength is higher for } \\
\text { concrete with bothreplacements coarseceramic aggregate and } \\
\text { ceramic sand than control concrete with traditional aggregates. }\end{array}$ & [15] \\
\hline $\begin{array}{c}\text { Conventional } \\
\text { Concrete }\end{array}$ & $\begin{array}{l}\text { As Fine and coarse } \\
\text { aggregate in sand } \\
\text { and gravel }\end{array}$ & $\begin{array}{l}\text { Sanitary ceramic } \\
\text { ware waste }\end{array}$ & $\begin{array}{r}100 \% \text { (for both } \\
\text { fine and coarse) }\end{array}$ & $\begin{array}{l}\text { Concrete mix produced } \\
\text { by } \% 100 \text { natural fine } \\
\text { and coarse aggregate }\end{array}$ & $\begin{array}{l}\text {-Compressive Strength } \\
\text {-Tensile Strength }\end{array}$ & 28 & $\begin{array}{l}\text { Compres sive strength of such concrete was higher of } 12 \% \text { and } \\
\text { tensile strength of } 30 \% \text { in comparis on to concrete with sand } \\
\text { and gravel aggregate. }\end{array}$ & [16] \\
\hline
\end{tabular}


Table 1. Comparison of some results for mechanical properties (cont.).

\begin{tabular}{|c|c|c|c|c|c|c|c|c|}
\hline \multirow[b]{2}{*}{$\begin{array}{l}\text { Type of } \\
\text { Product }\end{array}$} & \multirow[b]{2}{*}{$\begin{array}{l}\text { Using of Waste } \\
\text { Ceramic In The } \\
\text { Concrete } \\
\end{array}$} & \multicolumn{2}{|c|}{ Mixing Ratio of Concrete } & \multirow[b]{2}{*}{$\begin{array}{c}\text { Comparison } \\
\text { Criteria }\end{array}$} & \multirow[b]{2}{*}{ Experiments } & \multirow[b]{2}{*}{ Curing Day } & \multirow[b]{2}{*}{ Mechanical Property Findings } & \multirow[b]{2}{*}{ Ref. } \\
\hline & & $\begin{array}{c}\text { Waste Ceramic } \\
\text { Type }\end{array}$ & $\begin{array}{c}\text { Waste Ceramic } \\
\text { Ratio }\end{array}$ & & & & & \\
\hline $\begin{array}{l}\text { High- } \\
\text { Performance } \\
\text { Concrete }\end{array}$ & $\begin{array}{l}\text { As Fine and coarse } \\
\text { aggregate in sand } \\
\text { and gravel }\end{array}$ & $\begin{array}{l}\text { Earthenware } \\
\text { ceramic waste }\end{array}$ & $\begin{array}{l}15-30 \% \text { of } \\
\text { natural sand and } \\
20-50-100 \% \text { of } \\
\text { coarse mixed } \\
\text { aggregates. }\end{array}$ & $\begin{array}{l}\text { Concrete mix produced } \\
\text { by } \% 100 \text { natural river } \\
\text { sand mixes and } \\
\text { dolomitic gravel }\end{array}$ & $\begin{array}{l}\text {-Compressive Strength } \\
\text {-Flexural Strength } \\
\text {-Split Tensile Strength } \\
\text {-Elastic Modulus }\end{array}$ & $\begin{array}{c}1,7,28 \text { and } \\
180\end{array}$ & $\begin{array}{l}\text { Concrete madewith fine ceramic aggregate achieved a higher } \\
\text { compressive, flexural, splitting tensile strength and elastic } \\
\text { modulus strength in comparison to that of control concrete. } \\
\text { But, the concrete made with more than } 20 \% \text { of coarse ceramic } \\
\text { aggregates achieved a lower compressive, flexural, splitting } \\
\text { tensile strength and elastic modulus to that of control concrete. }\end{array}$ & {$[8]$} \\
\hline $\begin{array}{c}\text { Conventional } \\
\text { Concrete }\end{array}$ & $\begin{array}{l}\text { As Coarse } \\
\text { Aggregate }\end{array}$ & $\begin{array}{c}\text { Sanitary ceramic } \\
\text { waste }\end{array}$ & $(15,20$ and 25$) \%$ & $\begin{array}{l}\text { Concrete mix produced } \\
\text { by } \% 100 \text { natural coarse } \\
\text { aggregate. }\end{array}$ & $\begin{array}{l}\text {-Compressive Strength } \\
\text {-Split Tensile Strength }\end{array}$ & 7,28 and 90 & $\begin{array}{l}\text { The mechanical behavior, both in terms of compres sion and } \\
\text { splitting tensile strength, was better for therecycled concretes } \\
\text { than for the reference concrete. }\end{array}$ & [4] \\
\hline $\begin{array}{c}\text { Conventional } \\
\text { Concrete }\end{array}$ & $\begin{array}{l}\text { As Coarse } \\
\text { Aggregate }\end{array}$ & Ceramic Waste & $100 \%$ & $\begin{array}{l}\text { Concrete mix produced } \\
\text { by } \% 100 \text { conventional } \\
\text { coarse aggregate }\end{array}$ & -Compressive Strength & 28 & $\begin{array}{l}\text { The concrete mixes containing recycled ceramic waste } \\
\text { aggregates achieve strength levels between } 80 \text { to } 95 \% \\
\text { compared to the conventional concrete. }\end{array}$ & {$[17]$} \\
\hline $\begin{array}{c}\text { Conventional } \\
\text { Concrete }\end{array}$ & $\begin{array}{l}\text { As Coarse } \\
\text { Aggregate }\end{array}$ & $\begin{array}{c}\text { Ceramic } \\
\text { electrical } \\
\text { insulator wastes }\end{array}$ & $100 \%$ & $\begin{array}{l}\text { Concrete mix produced } \\
\text { by } \% 100 \text { conventional } \\
\text { crushed stone coarse } \\
\text { aggregate }\end{array}$ & $\begin{array}{l}\text {-Compressive Strength } \\
\text {-Flexural Strength } \\
\text {-Split Tensile Strength } \\
\text {-Elastic Modulus }\end{array}$ & 28 & $\begin{array}{l}\text { The compres sive, splitting tensile and flexural strengths of } \\
\text { ceramic waste coarse aggregate concrete arelower by } 3.8,18.2 \\
\text { and } 6 \% \text { respectively when compared to conventional concrete, } \\
\text { but ceramic waste coarse aggregate concrete pos ses ses lower } \\
\text { tensile to compres sive strength ratio. }\end{array}$ & [18] \\
\hline $\begin{array}{c}\text { Conventional } \\
\text { Concrete }\end{array}$ & $\begin{array}{l}\text { As Coarse } \\
\text { Aggregate }\end{array}$ & Crushed tiles & $(50-100) \%$ & $\begin{array}{l}\text { Concrete mix produced } \\
\text { by } \% 100 \text { conventional } \\
\text { crushed stone coarse } \\
\text { aggregate }\end{array}$ & $\begin{array}{l}\text { - Compressive Strength } \\
\text {-Flexural Strength } \\
\text {-Split Tensile Strength }\end{array}$ & 7,28 & $\begin{array}{l}\text { In general, concretes made with crushed tile as coarse } \\
\text { aggregate showed higher compressive, tensile, and flexural } \\
\text { strengths than control concrete. }\end{array}$ & [19] \\
\hline $\begin{array}{c}\text { Non-Structural } \\
\text { Concrete }\end{array}$ & $\begin{array}{l}\text { As Coarse } \\
\text { Aggregate }\end{array}$ & $\begin{array}{c}\text { Ceramic hollow } \\
\text { bricks }\end{array}$ & $\begin{array}{c}(33,66 \text { and } \\
100) \%\end{array}$ & $\begin{array}{l}\text { Concrete mix produced } \\
\text { by } \% 100 \text { coarse } \\
\text { limestone aggregate }\end{array}$ & $\begin{array}{l}\text {-Compressive Strength } \\
\text {-Flexural Strength }\end{array}$ & 28 & $\begin{array}{l}\text { The compressive and flexural strength, decreased with the } \\
\text { percentage of replacement of limestone aggregates with } \\
\text { ceramic aggregates increase. The decrease in compressive } \\
\text { strength is higher than that in the flexural strength. }\end{array}$ & {$[6]$} \\
\hline $\begin{array}{l}\text { Portland Blast } \\
\text { Furnace } \\
\text { Cement Type } \\
\text { B Concretes }\end{array}$ & $\begin{array}{l}\text { As Coarse } \\
\text { Aggregate }\end{array}$ & $\begin{array}{l}\text { Porous ceramic } \\
\text { waste aggregate } \\
\text { (PCA) }\end{array}$ & $(10$ and 20$) \%$ & $\begin{array}{l}\text { Concrete mix produced } \\
\text { by } \% 100 \text { crushed gravel } \\
\text { aggregate }\end{array}$ & $\begin{array}{l}\text {-Compressive Strength } \\
\text {-Shrinkage }\end{array}$ & $\begin{array}{l}3,7 \text { and } 28 \\
\text { (internal } \\
\text { curing) }\end{array}$ & $\begin{array}{l}\text { A } 10 \% \text { replacement of coarse aggregate by PCA was more } \\
\text { effective in improving compressive strength than a } 20 \% \\
\text { replacement by PCA at the early ages of } 3 \text { and } 7 \text { days, } \\
\text { independent of exposure conditions. Internal curing using PCA } \\
\text { to replace part of the corrse aggregate was not effective in } \\
\text { reducing autogenous shrinkage. }\end{array}$ & [20] \\
\hline
\end{tabular}


Table 2. Comparison of some results for durability properties.

\begin{tabular}{|c|c|c|c|c|c|c|c|}
\hline \multirow[b]{2}{*}{$\begin{array}{l}\text { Type of } \\
\text { Product }\end{array}$} & \multirow[b]{2}{*}{$\begin{array}{l}\text { Using of Waste } \\
\text { Ceramic In The } \\
\text { Concrete }\end{array}$} & \multicolumn{2}{|c|}{ Mixing Ratio of Concrete } & \multirow[b]{2}{*}{$\begin{array}{c}\text { Comparison } \\
\text { Criteria }\end{array}$} & \multirow[b]{2}{*}{ Experiments } & \multirow[b]{2}{*}{ Durability Results } & \multirow[b]{2}{*}{ Ref. } \\
\hline & & $\begin{array}{c}\text { Waste Ceramic } \\
\text { Type }\end{array}$ & $\begin{array}{c}\text { Waste Ceramic } \\
\text { Ratio }\end{array}$ & & & & \\
\hline $\begin{array}{c}\text { Normal } \\
\text { Mortar Mixing }\end{array}$ & $\begin{array}{l}\text { As Fine Aggregate } \\
\text { in Sand }\end{array}$ & $\begin{array}{l}\text { Porcelain insulator } \\
\text { waste (CWA) }\end{array}$ & $100 \%$ & $\begin{array}{l}\text { Mortar mix produced } \\
\text { by } \% 100 \text { typical river } \\
\text { sand (RS) }\end{array}$ & -Chloride Penetration & $\begin{array}{l}\text { It quantitatively indicated that the CWA mortars had lower apparant } \\
\text { chloride diffusion coefficient than the RS mortars }\end{array}$ & [11] \\
\hline $\begin{array}{l}\text { Conventional } \\
\text { Concrete }\end{array}$ & $\begin{array}{l}\text { As Fine Aggregate } \\
\text { in Sand }\end{array}$ & $\begin{array}{l}\text { Crushed ceramic } \\
\text { waste (CC) }\end{array}$ & $(40-50-60) \%$ & $\begin{array}{l}\text { Concrete mix produced } \\
\text { by } \% 100 \text { conventional } \\
\text { crushed fine aggregates }\end{array}$ & $\begin{array}{l}\text {-Abrasion Resistance } \\
\text {-Chloride Penetration }\end{array}$ & $\begin{array}{l}\text { Abrasion resistance of concrete was strongly influenced by its } \\
\text { compressive strength and crushed ceramic. Measurement of } \\
\text { chloride penetration depths correlated well with the differences } \\
\text { between additive type and replacement percentage of the mixtures. } \\
\text { Crushed ceramic } 60 \% \text { specimens were considerablymore resistant } \\
\text { to chloride ingress than those of other specimens. }\end{array}$ & [13] \\
\hline $\begin{array}{l}\text { Conventional } \\
\text { Concrete }\end{array}$ & $\begin{array}{l}\text { As Fine Aggregate } \\
\text { in CEN Reference } \\
\text { Sand }\end{array}$ & $\begin{array}{c}\text { Sanitary ceramic } \\
\text { waste }\end{array}$ & $(10,15$ and 20$) \%$ & $\begin{array}{l}\text { Concrete mix produced } \\
\text { by } \% 100 \text { natural sand }\end{array}$ & -Freeze-Thaw Resistance & $\begin{array}{l}\text { The freeze-thaw resistance results were concluding that ground } \\
\text { ceramic waste addition did not have any influence on compressive } \\
\text { strength up to } 25 \text { cycles, the observed behavior being similar for all } \\
\text { tested mortars. Conversely, freeze-thaw was found to affect } \\
\text { negatively the flexural strength of all tested mortars, the reduction } \\
\text { increasing with the ceramic waste content. }\end{array}$ & [14] \\
\hline $\begin{array}{l}\text { Conventional } \\
\text { Concrete }\end{array}$ & $\begin{array}{c}\text { As Fine and coarse } \\
\text { aggregate in sand } \\
\text { and gravel }\end{array}$ & $\begin{array}{l}\text { Sanitary ceramic } \\
\text { ware waste }\end{array}$ & $\begin{array}{l}100 \% \text { (for both fine } \\
\text { and coarse) }\end{array}$ & $\begin{array}{l}\text { Concrete mix produced } \\
\text { by } \% 100 \text { natural fine } \\
\text { and coarse aggregate }\end{array}$ & $\begin{array}{l}\text {-High Temp. Resist. } \\
\text {-Abrasion Resistance }\end{array}$ & $\begin{array}{l}\text { Abrasion resistance of concrete with ceramic sanitary ware } \\
\text { aggregate is higher by about } 20 \% \text { than abrasionresistance of gravel } \\
\text { concrete. Compressive strength of concrete with ceramic aggregate } \\
\text { decreased immediately after heating by } 46 \% \text {, in comparison to } \\
\text { strength of unheated concrete, whereas tensile strength decreased by } \\
54 \% \text {; strength loss was similar to other types of concrete, however } \\
\text { high initial strength made the strength of this concrete still high after } \\
\text { heating. }\end{array}$ & [16] \\
\hline $\begin{array}{l}\text { Conventional } \\
\text { Concrete }\end{array}$ & $\begin{array}{l}\text { As Fine and coarse } \\
\text { aggregate in sand } \\
\text { and gravel }\end{array}$ & $\begin{array}{c}\text { Brick, blocks and } \\
\text { roof tiles - wall, floor } \\
\text { tiles and sanitary } \\
\text { ware }\end{array}$ & $\begin{array}{l}100 \% \text { (for both fine } \\
\text { and coarse) }\end{array}$ & $\begin{array}{l}\text { Concrete mix produced } \\
\text { by } \% 100 \text { natural fine } \\
\text { and coarse aggregate }\end{array}$ & $\begin{array}{l}\text {-Capillary Water Absorb. } \\
\text {-Oxygen Permeability } \\
\text {-Chloride Penetration }\end{array}$ & $\begin{array}{l}\text { As for capillarity water ab sorption coefficients the differences are } \\
\text { rather important since capillary water abs orption for control } \\
\text { concrete (with traditional aggregates) almost doubles the capillarity } \\
\text { water absopption coefficient of ceramic aggregates based concrete. } \\
\text { The oxygen permeability results confirm the good performance of } \\
\text { the concrete mixtures with ceramic aggregates. As for the chloride } \\
\text { diffusion it once more confirms the good performance of ceramic } \\
\text { sand and coarse ceramic aggregate based concrete. }\end{array}$ & [15] \\
\hline $\begin{array}{l}\text { High- } \\
\text { Performance } \\
\text { Concrete }\end{array}$ & $\begin{array}{l}\text { As Fine and coarse } \\
\text { aggregate in sand } \\
\text { and gravel }\end{array}$ & $\begin{array}{c}\text { Earthenware ceramic } \\
\text { waste }\end{array}$ & $\begin{array}{l}15-30 \% \text { of natural } \\
\text { sand and } 20-50- \\
100 \% \text { of coarse } \\
\text { mixed aggregates. }\end{array}$ & $\begin{array}{l}\text { Concrete mix produced } \\
\text { by } \% 100 \text { natural river } \\
\text { sand mixes and } \\
\text { dolomitic gravel }\end{array}$ & $\begin{array}{l}\text {-Ultras onic Pulse Veloc. } \\
\text {-Capillary Water Absorb. } \\
\text {-Chloride Penetration }\end{array}$ & $\begin{array}{l}\text { Although the capillary ab sorption coefficient and ultras onic pulse } \\
\text { velocity values were worse than those of conventional concrete, the } \\
\text { chloride ionpenetration, after } 180 \text { days, was lower in concretes } \\
\text { made with ceramic fine aggregates. }\end{array}$ & {$[8]$} \\
\hline
\end{tabular}


Table 2. Comparison of some results for durability properties (cont.).

\begin{tabular}{|c|c|c|c|c|c|c|c|}
\hline \multirow[b]{2}{*}{$\begin{array}{l}\text { Type of } \\
\text { Product }\end{array}$} & \multirow[b]{2}{*}{$\begin{array}{l}\text { Using of Waste } \\
\text { Ceramic In The } \\
\text { Concrete }\end{array}$} & \multicolumn{2}{|c|}{ Mixing Ratio of Concrete } & \multirow[b]{2}{*}{$\begin{array}{l}\text { Comparison } \\
\text { Criteria }\end{array}$} & \multirow[b]{2}{*}{ Experiments } & \multirow[b]{2}{*}{ Durability Results } & \multirow[b]{2}{*}{ Ref. } \\
\hline & & $\begin{array}{c}\text { Waste Ceramic } \\
\text { Type }\end{array}$ & $\begin{array}{c}\text { Waste Ceramic } \\
\text { Ratio }\end{array}$ & & & & \\
\hline $\begin{array}{l}\text { Non-Structural } \\
\text { Concrete }\end{array}$ & $\begin{array}{l}\text { As Coarse } \\
\text { Aggregate }\end{array}$ & $\begin{array}{c}\text { Ceramic hollow } \\
\text { bricks }\end{array}$ & $(33,66$ and 100$) \%$ & $\begin{array}{l}\text { Concrete mix produced } \\
\text { by } \% 100 \text { coarse } \\
\text { limestone aggregate }\end{array}$ & $\begin{array}{l}\text {-Capillary Water Absorb. } \\
\text {-Immersion Water Absorb } \\
\text {-Abrasion Resistance }\end{array}$ & $\begin{array}{l}\text { The durability of this type of concrete may tum out to be its major } \\
\text { insufficiency, since water absorption either by immersion or } \\
\text { capillarity increases very regularly and significantly with the } \\
\text { proportion of ceramic aggregates on the concrete mix. Abrasion } \\
\text { resistance is precisely the one in which the concrete produced with } \\
\text { recycled ceramic aggregates shows an excellent performance, even } \\
\text { better than the reference concrete. }\end{array}$ & [21] \\
\hline $\begin{array}{l}\text { Conventional } \\
\text { Concrete }\end{array}$ & $\begin{array}{l}\text { As Coarse } \\
\text { Aggregate }\end{array}$ & $\begin{array}{c}\text { Sanitary ceramic } \\
\text { waste }\end{array}$ & $(20$ and 25$) \%$ & $\begin{array}{l}\text { Concrete mix produced } \\
\text { by } \% 100 \text { natural coarse } \\
\text { aggregate. }\end{array}$ & -Gas Permeability & $\begin{array}{l}\text { According to testresults, micro-poros ty and gas permeability, } \mathrm{O}_{2} \\
\text { and } \mathrm{CO}_{2} \text { permesbility were similar in the reference concrete and the } \\
\text { concretes containing recycled sanitary ware as a partial replacement } \\
\text { for conventional aggregate. }\end{array}$ & {$[7]$} \\
\hline $\begin{array}{l}\text { Conventional } \\
\text { Concrete }\end{array}$ & $\begin{array}{l}\text { As Coarse } \\
\text { Aggregate }\end{array}$ & $\begin{array}{c}\text { Sanitary ceramic } \\
\text { waste }\end{array}$ & $(20$ and 25$) \%$ & $\begin{array}{l}\text { Concrete mix produced } \\
\text { by } \% 100 \text { natural coarse } \\
\text { aggregate. }\end{array}$ & -Freeze-Thaw Resistance & $\begin{array}{l}\text { Sanitary ware industry aggregate is more resistant to temperature } \\
\text { change than natural coarse aggregate. The new concrete is more } \\
\text { freeze-thawresistant than conventional concrete. The scaling rate is } \\
\text { lower and the cracks are narrower in recycled concrete. Both effects } \\
\text { are accentuated with rising replacement ratios. }\end{array}$ & [9] \\
\hline $\begin{array}{l}\text { Conventional } \\
\text { Concrete }\end{array}$ & $\begin{array}{l}\text { As Coarse } \\
\text { Aggregate }\end{array}$ & $\begin{array}{c}\text { Sanitary ceramic } \\
\text { waste }\end{array}$ & $(20$ and 25$) \%$ & $\begin{array}{l}\text { Concrete mix produced } \\
\text { by } \% 100 \text { natural coarse } \\
\text { aggregate. }\end{array}$ & $\begin{array}{l}\text {-Water Resistance } \\
\text {-Porosity } \\
\text {-Sorptivity }\end{array}$ & $\begin{array}{l}\text { The maximum depth of water penetration is no greater in recycled } \\
\text { aggregate than natural aggregate concretes, and although the } \\
\text { average value is somewhat higher in the former, it never exceeds } 30 \\
\text { mm. The inclusion of ceramic sanitary ware aggregate raises total } \\
\text { porosity slightly and modifies pore size distribution, with an } \\
\text { increase in the volume of capillary pores at the expense of macro } \\
\text { pores. The concretes with recycled ceramic aggregate have greater } \\
\text { sorptivity than conventional concretes, since the values are } \\
\text { consistentlyunder } 3 \mathrm{~mm} / \mathrm{h}^{03} \text {, these may consequently be regarded } \\
\text { as durable materials. }\end{array}$ & [4] \\
\hline $\begin{array}{l}\text { Conventional } \\
\text { Concrete }\end{array}$ & $\begin{array}{l}\text { As Coarse } \\
\text { Aggregate }\end{array}$ & $\begin{array}{l}\text { Ceramic electrical } \\
\text { insulator wastes }\end{array}$ & $100 \%$ & $\begin{array}{l}\text { Concrete mix produced } \\
\text { by } \% 100 \text { conventional } \\
\text { crushed stone coarse } \\
\text { aggregate }\end{array}$ & $\begin{array}{l}\text {-Capillary Water Absorb. } \\
\text { - Sorptivity } \\
\text {-Chloride Penetration }\end{array}$ & $\begin{array}{l}\text { The basic trend of permeation characteristics of the ceramic } \\
\text { electrical insulator waste coarse aggregate concrete is similar to } \\
\text { those of the conventional concrete. The permeation characteristic } \\
\text { values increase with increase in water-cement ratio for both the } \\
\text { ceramic electrical in sulator waste coarse aggregate concrete and the } \\
\text { conventional concrete. }\end{array}$ & [18] \\
\hline
\end{tabular}




\section{Conclusions}

In this study, effects of waste ceramic on some mechanical and durability properties of conventional concrete were investigated. Considering all of the results and the findings in the literature, it was found that, using of waste ceramic in the conventional concrete as fine/coarse aggregate was positively affected on these mechanical and durability properties of concrete. Consequently, the green and sustainable concretes would be obtained by partial substitution of waste ceramic aggregates from different ceramics industry can be used for structural purposes.

\section{References}

[1] F. Puertas, M. T. Blanco-Varela, and T. Vazquez, "Behavior of cement mortars containing an industrial waste from aluminum refining Stability in $\mathrm{Ca}(\mathrm{OH})_{2}$ solutions," Cement and Concrete Research, vol. 29, pp. 1673-1680, 1999.

[2] M. Fernandes, A. Sousa, and A. Dias, "Environmental impact and emissions trade ceramic industry- A case study," Portuguese Association of Ceramic Industry APICER, Portuguese, 2004.

[3] F. Pacheco-Torgal, and S. Jalali, "Compressive strength and durability properties of ceramic wastes based concrete," Materials and Structures, vol. 44, pp. 155-167, 2011.

[4] C. Medina, M. I. Sanchez de Rojas, and M. Frias, "Reuse of sanitary ceramic wastes as coarse aggregate in eco-efficient concretes," Cement \& Concrete Composites, vol. 34, pp. 48-54, 2012.

[5] R. M. Senthamarai, and P.D. Manoharan, "Concrete with ceramic waste aggregate," Cement \& Concrete Composites, vol. 27, pp. 910-913, 2005.

[6] J. Brito, A.S. Pereira, and J.R. Correia, "Mechanical behaviour of non-structural concrete made with recycled ceramic aggregates", Cement \& Concrete Composites, vol. 27, pp. 429-433, 2004.

[7] C. Medina, M. Frias, M. I. Sanchez de Rojas, C. Thomas, and J.A. Polanco, "Gas permeability in concrete containing recycled ceramic sanitary ware aggregate," Construction and Building Materials, vol. 37, pp. 597-605, 2012.

[8] A. Gonzalez-Corominas, and M. Etxeberria, "Properties of high performance concrete made with recycled fine ceramic and coarse mixed aggregates," Construction and Building Materials, vol. 68, pp. 618-626, 2014.

[9] C. Medina, M. I. Sanchez de Rojas, and M. Frias, M, "Freeze-thaw durability of recycled concrete containing ceramic aggregate," Journal of Cleaner Production, vol. 40, pp. 151-160, 2013.

[10] P. Torkittikul, and A. Chaipanich, "Utilization of ceramic waste as fine aggregate within Portland cement and fly ash concretes," Cement \& Concrete Composites, vol. 32, pp. 440-449, 2010.

[11] H. Higashiyama, K. Yamauchi, M. Sappakittipakorn, M. Sano, and O. Takahashi, "A visual investigation on chloride ingress into ceramic waste aggregate mortars having different water to cement ratios," Construction and Building Materials, vol. 40, pp. 1021-1028, 2013.

[12] V. Lopez, B. Llamas, A. Juan, C.M. Moran, and I. Guerra, "Eco-efficient concretes: impact of the use of white ceramic powder on the mechanical properties of concrete," Biosystems engineering, Vol. 96, pp. 559-564, 2007.

[13] H. Binici, "Effect of crushed ceramic and basaltic pumice as fine aggregates on concrete mortars properties," Construction and Building Materials, vol. 21 pp. 1191-1197, 2007.

[14] W. Jackiewicz-Rek, K. Załęgowski, A. Garbacz, and B. Bissonnette, "Properties of cement mortars modified with ceramic waste fillers," Procedia Engineering, vol. 108, pp. 681-687, 2015.

[15] F. Pacheco-Torgal, and S. Jalali, "Reusing ceramic wastes in concrete," Construction and Building Materials, vol. 24, pp. 832-838, 2010.

[16] A. Halicka, P. Ogrodnik, and B. Zegardlo, "Using ceramic sanitary ware waste as concrete aggregate," Construction and Building Materials, vol. 48, pp. 295-305, 2013.

[17] A.M.M. Al Bakri, M. N. Norazian, H. Kamarudin, M.A.A. Mohd Salleh, and A. Alida, "Strength of concrete based cement using recycle ceramic waste as aggregate," Advanced Materials Research, vol. 740, pp. 734-738, 2013. 
[18] R.M. Senthamarai, P.D. Manoharan, and D. Gobinath, "Concrete made from ceramic industry waste: Durability properties," Construction and Building Materials, vol. 25, pp. 2413-2419, 2011.

[19] A.R. Khaloo, "Crushed Tile Coarse Aggregate Concrete," Cement, Concrete, and Aggregates, vol. 17, pp. 119-125, 1995.

[20] R. Sato, A. Shigematsu, T. Nukushina, and M. Kimura, "Improvement of properties of portland blast furnace cement type b concrete by internal curing using ceramic roof material waste," Journal of Materials in Civil Engineering, vol. 23, PP. 777-782, 2011.

[21] J.R. Correia, J. Brito, A.S. Pereira, "Effects on concrete durability of using recycled ceramic aggregates," Materials and Structures, vol. 39, pp. 169-177,2006.

\section{BIBLIOGRAPHY OF AUTHORS}
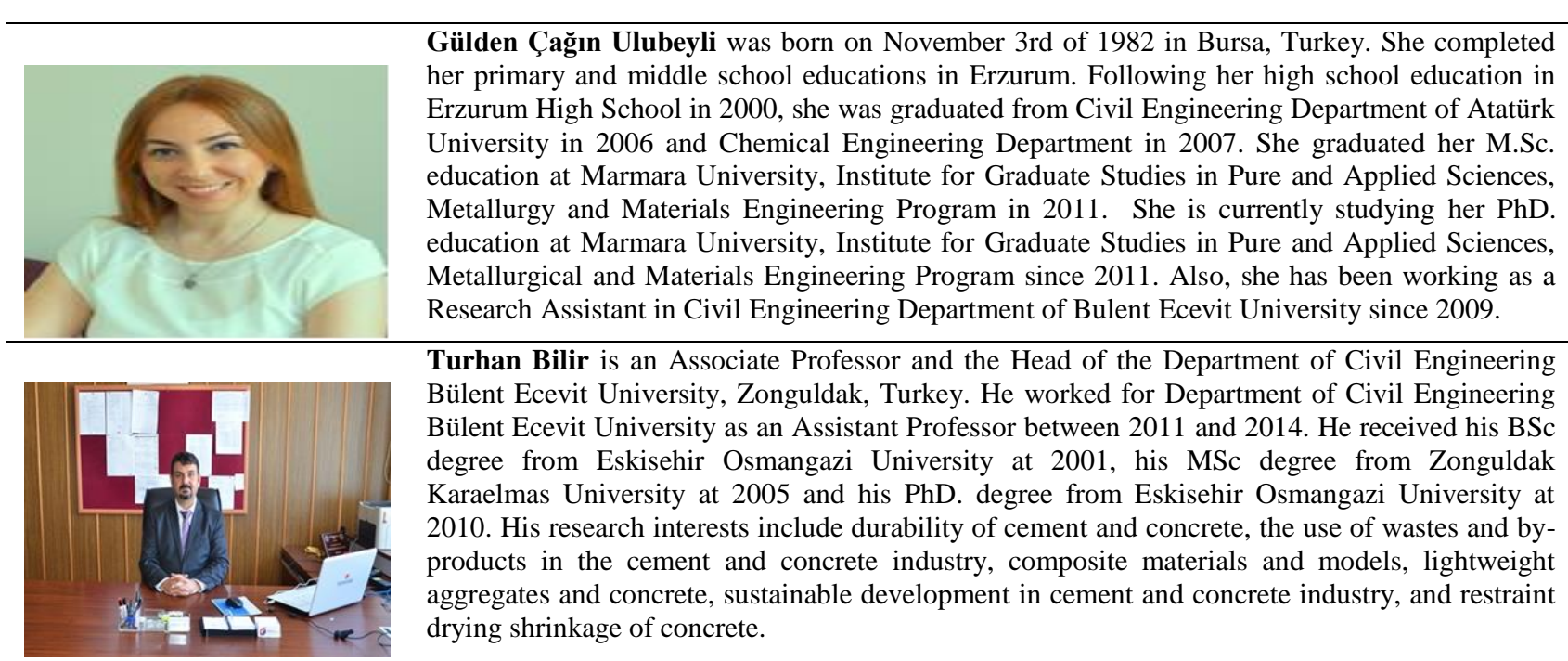

Turhan Bilir is an Associate Professor and the Head of the Department of Civil Engineering Bülent Ecevit University, Zonguldak, Turkey. He worked for Department of Civil Engineering Bülent Ecevit University as an Assistant Professor between 2011 and 2014. He received his BSc degree from Eskisehir Osmangazi University at 2001, his MSc degree from Zonguldak Karaelmas University at 2005 and his $\mathrm{PhD}$. degree from Eskisehir Osmangazi University at 2010. His research interests include durability of cement and concrete, the use of wastes and byproducts in the cement and concrete industry, composite materials and models, lightweight aggregates and concrete, sustainable development in cement and concrete industry, and restraint drying shrinkage of concrete.

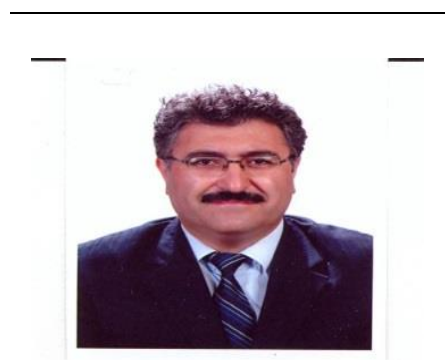

Recep Artır is a lecturer and Professor of Metallurgical and Materials Engineering. He received his BSc degree in Metallurgical Engineering from İstanbul Technical University, Turkey in 1985. He received his MSc degree in Metallurgical Engineering from Yildiz University, İstanbul, Turkey in 1988 and his PhD. degree from Sheffield University in 1994 in the UK. Currently, he carries out his teaching and research activities in Metallurgical and Materials Engineering department at Marmara University. His research interests include iron and steel production, recycling of industrial wastes, ceramic and refractory materials, biomaterials and surface modification of materials. 